\title{
Appraisal of urban lake water quality through numerical index, multivariate statistics and earth observation data sets
}

\author{
S. K. Singh ${ }^{1} \cdot$ Prafull Singh $^{2} \cdot$ S. K. Gautam ${ }^{3}$
}

Received: 6 January 2015/Revised: 23 May 2015/Accepted: 5 July 2015/Published online: 7 August 2015

(C) Islamic Azad University (IAU) 2015

\begin{abstract}
The earth observation data sets were employed to study the land use/land cover change in study area from year 2000-2010. Vegetation, built-up area and agriculture classes had shown maximum changes. The lake water samples were analyzed, and further, Water Quality Index (WQI) was computed to categorize the lake water. The average value of WQI is $64.52,52.23$ and 42.45 in premonsoon, monsoon and post-monsoon seasons, respectively. Generally, pre-monsoon samples have higher number of polluted samples. Moreover, we applied the multivariate statistical techniques for handling large and complex data sets in order to get better information about the lake water quality. Factor analysis and principal component analysis are applied to understand the latent structure of the data sets, and we have identified a total of four factors in pre-monsoon, three factors in monsoon and three factors in post-monsoon season, which are responsible for the whole data structure. These factors have explained that $90.908,89.078$ and $85.456 \%$ of the cumulative percentage variance of the pre-monsoon, monsoon and post-monsoon data sets. Overall analysis reveals that the agricultural runoff, waste disposal, leaching and irrigation with wastewater, land transformation in the surrounding areas are the main causes of lake water pollution followed by
\end{abstract}

Prafull Singh

singhgeoscience@rediffmail.com

1 K. Banerjee Centre of Atmospheric and Ocean Studies, IIDS, Nehru Science Centre, University of Allahabad, Allahabad 211002, India

2 Amity Institute of Geo-Informatics and Remote Sensing, Amity University, Sector 125, Noida 201303, India

3 School of Environmental Sciences, Jawaharlal Nehru University, New Delhi 110067, India some degree of pollution from geogenic sources such as rock weathering. Hence, there is an urgent need of proper attention and management of resources.

Keywords Lake - Land use/land cover change .

Pollution $\cdot$ Earth observation data sets

\section{Introduction}

There are very limited studies on lake in India. In recent decades, the developing countries are witnessed of water pollution after industrialization, and unprecedented population growth (Singh et al. 2013a, b, c, d; Oişte 2014; Thakur et al. 2015; Gautam et al. 2015). The increasing population around the urban lake has continuously encroached lake area due to demand of land and water (Singh et al. 2010) and acts as waste dumping sites which have many adverse effects on humans (Rast ; Mishra and Garg 2011). The direct discharge of sewage from the households into the urban lake and the surface runoff brings sediment, nutrients and chemicals from catchment area into lake, and hence, they get polluted. These excessive nutrients mainly nitrate and phosphates promote excessive growth of aquatic plants in the lake and make them anaerobic (Gautam et al. 2013) and destroy the aquatic flora and fauna. Such undesirable change in water chemistry (Akoto and Adiyiah 2007) brings deterioration of lake water quality.

With rapid urban development since 1956, when Bhopal became the state capital of Madhya Pradesh, the lake has simultaneously been affected by increased inflows of silt, untreated sewage, nutrients and pesticides from urban and rural areas, and growing domestic water demand and treatment costs for the municipal water supply. Therefore, 
the regular monitoring and assessment are a prerequisite to understand the water quality. Many governments are now seeing other approaches in response to increasing awareness of degrading lake water resources and growing concern over the significant fiscal burden of agricultural subsidies.

Earth observation data sets, e.g., satellite images, are quite useful, which could be used for synoptic representation of any area (Srivastava et al. 2010). Land use/land cover change (LULCC) quantification is one of the major application of earth observation data sets, and it is important for assessing global environmental change processes and helps in making new policies and optimizing the maximum use of natural resources in sustainable manners (Srivastava et al. 2012). The land use/land cover (LULC) types, such as agricultural land and urban area, are associated with human activities that often affect the water quality and change the aquatic ecological environment; hence, monitoring spatial-temporal changes is essential to understand the driving factors which influence the water quality of any area. Amin et al. (2014) and Mishra and Garg (2011) has did research on lake of India by implying the satellite data.

According to Singh et al. (2015), the concept of water quality to categorize water according to its degree of purity or pollution dated back to year 1848. Around the same time, the importance of water quality to public health was recognized in the UK (Snow 1856). Water Quality Index (WQI) methodologies have been developed to provide single number that expresses the overall water quality at a certain location and time, based on several water quality parameters (Parmar and Bhardwaj 2013; Vasanthavigar et al. 2010; Avvannavar and Shrihari 2008; Singh et al. 2015) and can be used to provide the overall summaries of water quality on a scientific basis. Parmer and Bhardwaj (2013) have applied WQI and fractal dimension approach to study the water of Harike lake on the confluence of Beas and Sutlej rivers of Punjab (India). Many researchers have discussed the importance and applicability of WQI for water characterization (Couillard and Lefebvre 1985; House and Newsome 1989; Bordalo et al. 2001; Smith 1989; Swamee Tyagi 2000; Sanchez et al. 2007).

In combination with remote sensing water quality, the use of multivariate statistical techniques offers a detailed understanding of water quality parameters and possible factors that influence the water quality behavior (Srivastava et al. 2012). Principal component analysis (PCA) and factor analysis (FA) offer a valuable tool for consistent, reliable, effective management of water resources (Srivastava et al. 2012; Singh et al. 2009, 2013d, 2015). Many authors in past have used multivariate statistical techniques to characterize and evaluate surface and groundwater quality and have found it interesting for studying the variations caused by geogenic and anthropogenic factors (Shrestha and Kazama 2007; Singh et al. 2005). For understanding the lake water quality, multivariate statistical techniques integrated with remote sensing, and WQI (Srivastava et al. 2012) could be used for identification of the possible factor/sources that influences urban lake water quality.

As the study area occupied by hard basaltic terrain and groundwater resource are limited. Hence, largely the water supply in urban areas setteled at hard rock terrain depends on lake water too for drinking and small scale industrial purposes. The water supply of bhopal urban area mainly depends on the Bhopal lake for drinking, irrigation and small scale industries.

The specific objective of this research was focused on to quantify the historical changes in LULC using satellite data sets and its probable impact on the lake water quality with integration of statistical techniques to know the pollution status of Bhopal lake and to categorize lake water by WQI method. The findings of the study will be useful for the restoration of Bhopal lake.

\section{Materials and methods}

\section{Description of study area}

District Bhopal [latitudes $20^{\circ} 10^{\prime}-23^{\circ} 20^{\prime} \mathrm{N}$ and longitudes $77^{\circ} 15^{\prime}-77^{\circ} 25^{\prime} \mathrm{E}$ (Fig. 1)] is the capital city of the state of Madhya Pradesh, India. Upper lake commonly known as Bhoj wetland is the main lake of the city and provides water to the dwellers. The lake surrounded by natural landscape, settlements and agricultural fields. The average annual rainfall is $1270 \mathrm{~mm}$. The southern part of the city receives more rainfall than northern part of the city. The maximum rainfall takes place during the month of July.

The area is drained by small drains which are lastly contributing water to the river Betwa in the downstream. Bhopal has been growing at a fast rate due to urban development and industrialization, in search of better facilities and for educational purposes. The major part of the city is covered by Vindhyan hills and by basaltic Deccan trap. The Deccan trap covers almost one-third of the area followed by Vindhyan sandstone (Singh and Singh 2012). In Deccan trap basalts, aquifer is encountered at shallow depth and in Vindhyan sandstone depth ranges more than 150 meter below ground level (mbgl). The water supply to Bhopal city mainly comes from surface water bodies and small amount by groundwater. Nowadays, a number of boreholes/tube wells are drilled in the area without consideration of hydrological status of the aquifer formation to meet the water requirement, and this unaware drilling has also led to the declining trend of water level and also failure of well in successive years. Upper lake is a 
Fig. 1 Location map of Bhopal Lake, MP, India

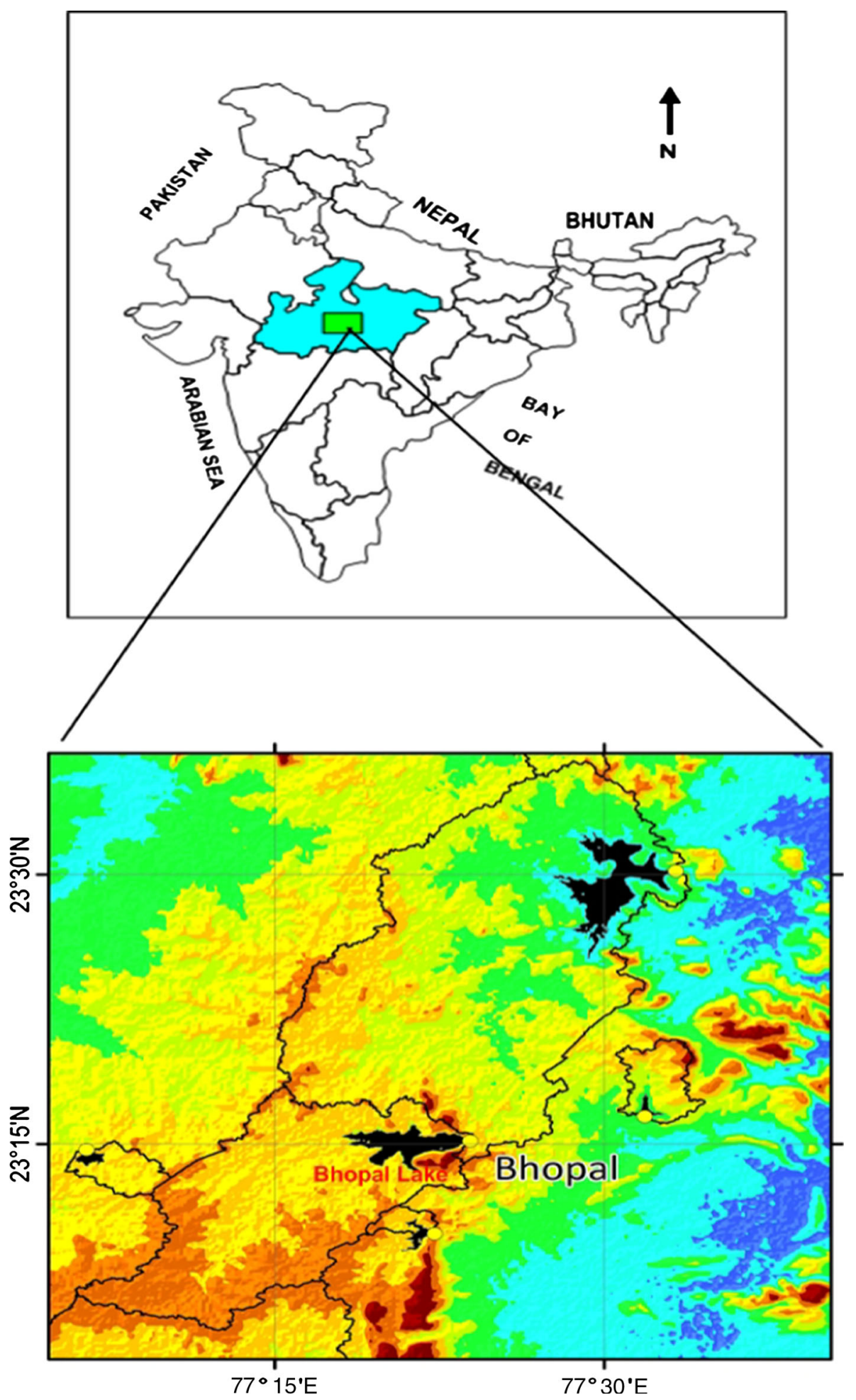

major source of drinking water for the urban residents, serving around $40 \%$ of the residents with nearly $140,000 \mathrm{~m}^{3}$ of water per day. Bada talaab, along with the nearby Chhota talaab, constitutes Bhoj wetland, which is now a Ramsar site. The two lakes support flora and fauna. White stork, blacknecked stork, barheaded goose, spoonbill, etc., which have been rare sightings in the past, have started appearing. A recent phenomenon is the gathering of 100-120 sarus cranes in the lake. The largest bird of India, sarus crane (Grusantigone), is known for its size, majestic flight and lifetime pairing. Flora 106 species of Macrophytes (belonging to 87 genera of 46 families), 
which includes 14 rare species and 208 species of Phytoplankton comprising 106 species of Chlorophyceae, 37 species of Cyano phyceae, 34 species of Euglenophyceae, 27 species of Bacilariophyceae and 4 species of Dinophyceae. Fauna 105 species of zooplanktons, which includes (rotifera 41, Protozoa 10, Cladocera 14, Copepoda 5, Ostracoda 9, Coleoptera 11, and Diptera 25). Fish fauna consist of 43 species (natural and cultured species), and 27 species of avifauna, 98 species of insects and more than 10 species of reptiles and amphibians (including 5 species of tortoise) have been recorded.

\section{Geology and geomorphology of the study area}

The Deccan trap sequence consists of multiple layers of solidified lava flows. It is more than $2000 \mathrm{~m}$ thick on its western margin and decreases in thickness eastward and occupies $\sim 5,00,000 \mathrm{~km}^{2}$ area spread over parts of Madhya Pradesh, Maharashtra, Gujarat, Andhra Pradesh and Karnataka (Singh et al. 2011, 2013a, b, c). The basaltic lava flows vary in color from dark gray to purple and pink. Each lava flow consists of an upper vesicular unit and a lower massive unit which may or may not be fractured/ jointed. Two lava flows at some places are separated by intertrappean sedimentary beds. Therefore, unlike other hard rocks, the Deccan trap behaves as a multiaquifer system, somewhat similar to a sedimentary rock sequence. Bhopal is occupied by the rocks of Vindhyan and Deccan trap basalt and alluvial formations. Hydrogeologically, area is divided into three major type's alluvium, Deccan trap and Vindhyan sandstones with small patches of shale which makes the major aquifers of the city.

In the study area, Deccan trap is sporadically distributed mainly in the form of linear patches. On the satellite image, this rock type is seen with distinct gray color with rough texture. The derivatives of Deccan trap rock are the black soils, which are seen on the satellite image as dark gray tone with smooth texture. The major geomorphic landforms within the catchment of Bhopal lake are pediplain, shallow weathered/shallow buried pediplain and pediplain weathered/buried with varying thickness. On the basis of thickness and composition of weathered material, the pediplain has been classified into shallow weathered pediplain and moderate weathered pediplain (Singh et al. 2013a, b, c). Most of the area covers under shallow pediplain; hence, this landform classified as good zone of groundwater and agricultural activity within the lake catchment.

\section{Data and Methodology}

The study is mainly based on laboratory based data, supplemented by primary information especially of social and economic characteristics.

\section{Land use/land cover}

The earth observation data sets used for the preparation of LULC maps of year 2000 and 2010 using Landsat satellite images. The multispectral satellite image from the Landsat data was geometrically rectified and registered with Survey of India (SOI) topographical sheets used as a reference for taking ground control points (GCP) by using UTM projection and WGS 84 datum. Further, all geocoded images were mosaic using ERDAS Imagine 9.1. Further, for assistance in the process of interpretation, SOI (55 E/7 and $55 \mathrm{E} / 8)$ at 1:50,000 scales was used as the reference map for interpretation of the basic information of the lake catchment (Table 1).

\section{Field and laboratory analysis}

Water samples were collected during month of January 2010-December 2010 on monthly time intervals in $1 \mathrm{~L}$ plastic bottles. Total of 15 sample collection sites were monitored for chemical pollutant analyses during premonsoon, monsoon and post-monsoon seasons. The collected samples were separated into three aliquots. All samples were stored at $4{ }^{\circ} \mathrm{C}$ for further analysis. Collection and analysis were performed as specified standard international methods (APHA, 1999). Total alkalinity (as $\mathrm{HCO}_{3}{ }^{-}$), total hardness, calcium, magnesium, chloride, phosphate, nitrate, biological oxygen demand (BOD) and chemical oxygen demand (COD) were measured from the collected samples on the monthly basis. Alkalinity is measured using a Hath field titration kit (through titration with $0.1 \mathrm{M} \mathrm{HCl})$. The major cations are $\left(\mathrm{Mg}^{2+}\right.$ and $\left.\mathrm{Ca}^{2+}\right)$ analyzed using an atomic absorption spectrophotometer. Major anions $\left(\mathrm{Cl}^{-}, \mathrm{NO}_{3}-\mathrm{N}\right.$ and $\left.\mathrm{PO}_{4}{ }^{3-}\right)$ for samples are undertaken by ion chromatography. The

Table 1 Different standard given by World Health Organization

\begin{tabular}{llll}
\hline Sr. no. & Parameters & Standard $\left(\mathrm{S}_{\mathrm{i}}\right)$ & $\mathrm{W}_{\mathrm{i}}$ \\
\hline 1 & Total alkalinity & 120 & 0.0084 \\
2 & Total hardness & 500 & 0.002 \\
3 & Calcium content & 75 & 0.0134 \\
4 & Magnesium content & 75 & 0.0134 \\
5 & Chloride & 250 & 0.004 \\
6 & Phosphate & 1.5 & 0.6689 \\
7 & Nitrate & 50 & 0.0201 \\
8 & BOD & 5 & 0.2007 \\
9 & COD & 14.5 & 0.0692 \\
& & & $\sum \mathrm{W}_{\mathrm{i}}=1$ \\
\hline
\end{tabular}

$V_{i}=0$ for the parameters except for $\mathrm{pH}$ and dissolved oxygen (D.O) (Sinha and Saxena 2006) 
methodological limitations starts from collection of samples, transportation, sample analysis in laboratory, instrumentation limitation in terms of sensitivity and precision, and interpretation of results. The sampling and analysis were performed according to APHA (1999). Methodological limitation of ion chromatography is equivalency, and a high concentration of any one ion also interferes with the resolution, and sometimes retention, of others. Sample dilution or gradient elution overcomes much interference. To resolve uncertainties of identification or quantitation, use the method of known additions. The most troublesome type of interference is termed "chemical" and results from the lack of absorption by atoms bound in molecular combination in the flame. This can occur when the flame is not hot enough to dissociate the molecules or when the dissociated atom is oxidized immediately to a compound that will not dissociate further at the flame temperature. Such interferences may be reduced or eliminated by adding specific elements or compounds to the sample solution. The precision and accuracy of the analysis are within $5 \%$ (evaluated through repeated analyses of standards and samples) (Singh et al. 2015). In the present study, we did not analyze any lake sediment and water for the metal analysis due to financial constraints which will be our future scope of research.

\section{Water Quality Index estimation}

WQI provides an unambiguous picture about the usability of water for different purposes such as drinking, irrigation and industrial usage (Singh et al. 2015). However, it is difficult to simplify surface and groundwater quality to a specific index because of its sensitive nature to inputs received from sources such as geogenic contribution, water-rock reactions, agricultural runoff, domestic and industrial wastes (Singh et al. 2012). However, the modified WQI by Tiwari and Mishra (1985) is useful and efficient method for assessing the quality of water and presently used by many scientists and water managers. To determine the suitability of the water for drinking purposes (Srivastava et al. 2012; Singh et al. 2015), WQI can be estimated by using the following methodology:

$\mathrm{WQI}=$ Anti $\log \left[\sum_{i=1}^{n} W_{i} \log _{10} q_{i}\right]$

where $W_{i}$ is the weighting factor computed using equation

$W_{i}=K / S_{i}$

$K$ is proportionality constant derived from Eq. 3
Table 2 Rating and category chart of WQI

\begin{tabular}{lll}
\hline Sr. no. & WQI level & Water quality rating \\
\hline 1 & $<25$ & Excellent \\
2 & $26-50$ & Good \\
3 & $51-75$ & Poor \\
4 & $76-100$ & Very Poor \\
5 & $>100$ & Unfit for drinking purposes \\
\hline
\end{tabular}

$K=\left[\frac{1}{\left(\sum_{i=1}^{n} 1 / S_{i}\right)}\right]$

where $S_{i}$ is the World Health Organization (WHO) standard values of the water quality parameter.

Quality rating $\left(q_{i}\right)$ is calculated using the formula,

$q_{i}=\left[\left(V_{\text {actual }}-V_{\text {ideal }}\right) /\left(V_{\text {standard }}-V_{\text {ideal }}\right)\right] \times 100$

where $q_{i}$ is quality rating of ith parameter for a total of $\mathrm{n}$ water quality parameters, $V_{\text {actual }}$ is the value of the water quality parameter obtained from laboratory analysis, $V_{\text {ideal }}$ is zero except for $\mathrm{pH}$ and D.O. and $V_{\text {standard }}$ is WHO standard of the water quality parameters (Table 1). The rating and category chart for WQI is represented through Table 2 .

\section{Multivariate statistical method}

The application of multivariate statistical techniques is very useful for classification, modeling and interpretation of large data sets which allow the reduction in dimensionality of the large data sets (Singh et al. 2009, 2015). FA/PCA techniques are applied for multivariate analysis of data sets of lake water quality. PCA is applied after standardizing the data sets through the z-scale transformation to avoid any misclassification (Singh et al. 2015). The principal component (PC) is expressed as:

$z_{i j}=a_{i 1} x_{1 j}+a_{i 2} x_{2 j}+a_{i 3} x_{3 j}+\cdots+a_{i m} x_{m j}$

where $a$ is the component loading, $z$ the component score, $x$ the measured value of a variable, $i$ the component number, $j$ the sample number, and $\mathrm{m}$ the total number of variables. The FA analysis attempts to reduce the contribution to less significant variables obtained from PCA and the new group of variables known as varifactors (VFs). VFs are extracted through rotating the axis defined by PCA. In FA, the basic concept is expressed in Eq. (6),

$z_{j i}=a_{f 1} f_{1 i}+a_{f 2} f_{2 i}+a_{f 3} f_{3 i}+\cdots+a_{f m} f_{m i}+e_{f i}$

where $z$ is the measured value of a variable, $a$ the factor loading, $f$ the factor score, $e$ the residual term accounting 
for errors or other sources of variation, $i$ the sample number, $j$ the variable number and $m$ the total number of factors.

\section{Results and discussion}

\section{Hydrochemistry of lake water}

The descriptive statistics of 12 physicochemical parameters at the 15 locations are summarized in Table 3 . The average value of total alkalinity 78.67, 60.07 and 57.20 was observed during the pre-monsoon, monsoon and postmonsoon seasons. Carbonate alkalinity average value was 13.19, 11.80 and 6.80, and bicarbonate alkalinity was $65.49,49.43$ and 50.96; total hardness average value was $85.25,94.77$ and 89.84, calcium hardness was 60.12, 67.10 and 68.58 and magnesium hardness was 25.14, 27.67 and 21.27 in the pre-monsoon, monsoon and post-monsoon seasons, respectively. Calcium and magnesium are an essential nutrient that is required by all living organisms. Calcium and magnesium are entirely derived from rock weathering. The sources of $\mathrm{Ca}$ mainly are carbonate rocks containing calcite $\left(\mathrm{CaCO}_{3}\right)$ and dolomite $\left[\left(\mathrm{CaMg}\left(\mathrm{CO}_{3}\right)_{2}\right]\right.$, with a lesser proportion derived from $\mathrm{Ca}$-silicate minerals. Calcium is usually one of the most important contributors to hardness. The average value of $\mathrm{Ca}$ was $25.25,28.18$ and 28.80, magnesium $6.11,6.72$ and 5.17 in the pre-monsoon, monsoon and post-monsoon seasons, respectively.
Chloride is extremely mobile and very much soluble in surface water. The main geogenic sources of chloride are sea salt and dissolution of halite $(\mathrm{NaCl})$ in bedded evaporites or dispersed in shales, and anthropogenic sources are domestic and industrial sewage, mining, and road salt runoff. The average value of chloride was $6.13,21.03$ and 19.35 in the all three seasons, respectively.

Phosphorus is a vital and often limiting nutrient. The most common minerals are apatite, which is calcium phosphate with variable amounts of hydroxyl-, chloro-, or fluoro-apatite and various impurities. Some other phosphate minerals contain aluminum or iron. The anthropogenic sources of phosphorus are domestic sewage, as the element is essential in metabolism, industrial sewage and household detergents. Phosphates and nitrates are the major cause of eutrophication problem in lakes. The average values of phosphate were $1.05,0.76$ and 0.62 , total phosphorous was $1.62,1.91$, and 1.80 , organic phosphorous was $1.13,1.16$ and 1.18 and nitrate was $0.73,0.73$ and 0.64 in the pre-monsoon, monsoon and post-monsoon season, respectively. Aqueous geochemistry behavior of nitrogen is strongly influenced by the vital importance of the element in plants and animal nutrition. The anthropogenic sources of nitrate in surface water are runoff from the agriculture field, and leachates from the landfill sites. The BOD was 3.83, 4.83 and 4.42, and COD was 29.60, 21.06 and 15.73 in the pre-monsoon, monsoon and post-monsoon season, respectively. The development activity and expansion of the city leading to discharge of waste water in the upper

Table 3 Physicochemical properties of lake water samples during the three seasons (all the parameters units are in $\mathrm{mg} / \mathrm{l}$ )

\begin{tabular}{|c|c|c|c|c|c|c|c|c|c|c|c|c|}
\hline \multirow[t]{2}{*}{ Parameters } & \multicolumn{4}{|c|}{ Pre-monsoon } & \multicolumn{4}{|c|}{ Monsoon } & \multicolumn{4}{|c|}{ Post-monsoon } \\
\hline & Max & Min & Avg & Std & Max & Min & Avg & Std & Max & Min & Avg & Std \\
\hline Total alkalinity & 129.60 & 61.60 & 78.67 & 18.55 & 98.00 & 49.00 & 60.07 & 12.03 & 78.67 & 46.67 & 57.20 & 7.50 \\
\hline Carbonate alkalinity & 17.60 & 7.00 & 13.19 & 2.95 & 16.67 & 7.00 & 11.80 & 2.78 & 11.33 & 4.00 & 6.80 & 2.30 \\
\hline Bicarbonate alkalinity & 118.40 & 46.00 & 65.49 & 19.84 & 94.50 & 36.50 & 49.43 & 13.99 & 76.00 & 42.67 & 50.96 & 8.06 \\
\hline Total hardness & 146.00 & 74.80 & 85.25 & 17.53 & 155.50 & 79.50 & 94.77 & 18.13 & 116.67 & 62.67 & 89.84 & 17.23 \\
\hline Ca hardness & 105.00 & 51.66 & 60.12 & 13.26 & 122.85 & 55.65 & 67.10 & 16.66 & 104.30 & 55.30 & 68.58 & 12.99 \\
\hline Mg hardness & 41.00 & 18.56 & 25.14 & 5.90 & 33.73 & 19.48 & 27.67 & 5.27 & 42.07 & 7.37 & 21.27 & 10.38 \\
\hline Calcium content & 44.10 & 21.70 & 25.25 & 5.57 & 51.60 & 23.37 & 28.18 & 7.00 & 43.81 & 23.23 & 28.80 & 5.46 \\
\hline Magnesium content & 9.96 & 4.51 & 6.11 & 1.43 & 8.20 & 4.73 & 6.72 & 1.28 & 10.22 & 1.79 & 5.17 & 2.52 \\
\hline Chloride & 31.17 & 12.99 & 16.13 & 4.27 & 35.21 & 16.23 & 21.03 & 4.54 & 27.64 & 15.65 & 19.35 & 2.83 \\
\hline Phosphate & 3.19 & 0.49 & 1.05 & 0.68 & 3.14 & 0.18 & 0.76 & 0.74 & 3.06 & 0.12 & 0.62 & 0.72 \\
\hline Total phosphorus & 3.56 & 0.94 & 1.62 & 0.71 & 4.05 & 1.15 & 1.91 & 0.8 & 3.93 & 1.03 & 1.80 & 0.80 \\
\hline Organic phosphorus & 2.31 & 0.43 & 1.13 & 0.47 & 2.33 & 0.45 & 1.16 & 0.47 & 2.66 & 0.55 & 1.18 & 0.51 \\
\hline Nitrate & 1.88 & 0.11 & 0.73 & 0.46 & 1.86 & 0.09 & 0.73 & 0.45 & 1.77 & 0.07 & 0.64 & 0.46 \\
\hline BOD & 4.88 & 3.08 & 3.83 & 0.56 & 11.60 & 3.40 & 4.83 & 1.94 & 10.00 & 2.00 & 4.42 & 2.60 \\
\hline COD & 44.80 & 23.20 & 29.60 & 4.70 & 35.00 & 16.06 & 21 & 4.75 & 30.67 & 12.00 & 15.73 & 4.37 \\
\hline
\end{tabular}


and lower lakes are serious threats to these water bodies (Bhopal City Development Plan, 2006). Dumping of solid waste in the open drains increases the BOD and COD of the water as well as makes it breeding ground for pathogenic bacteria, further leading to contamination of ground water (Bhopal City Development Plan 2006). Solid waste dumping in the surface water bodies leads to growth of invasive aquatic plant, which harms to the biodiversity (Bhopal City Development Plan 2006). Ponds are been abandoned due to siltation and growth of terrestrial and aquatic plants (Bhopal City Development Plan 2006).

\section{Water Quality Index (WQI)}

The WQI of different sites for lake water is mentioned in Table 4 . All the values calculated are explicitly higher than the limits, indicating very high pollution status of the samples during the pre-monsoon period. The analysis indicates that the maximum $(\max )(150.83)$ and minimum (min) (40.15) values of WQI are reported at BHADBHADA (U/13) and at KAMLA PARK, respectively, with standard deviation 27.66 in pre-monsoon season. The max (176.86) and min (19.97) values of WQI during postmonsoon are observed at BHADBHADA and at BISENKHEDI with standard deviation 38.75 in monsoon season.
The max (160.91) and min (14.82) values of WQI during post-monsoon are determined at BHADBHADA and at KHANUGAU with standard deviation 35.79. The detailed analysis showed that $6.66 \%$ samples unfit for drinking purposes in each season, $6.66 \%$ sample was very poor in pre-monsoon, monsoon and $13.33 \%$ sample poor in postmonsoon, $60 \%$ sample lay in the poor category in premonsoon season, $33.33 \%$ poor in monsoon season, while $13.33 \%$ sample in post-monsoon season was in poor category. In pre-monsoon season, $26.66 \%$ samples fall in good category, $26.66 \%$ in monsoon season, while $46.66 \%$ sample in the post-monsoon season. Only 26.66 and $33.33 \%$ samples fall in the category of excellent in the monsoon and post-monsoon seasons, respectively, and no sample was qualified for the excellent category in premonsoon season.

\section{LULC-based assessment of lake water quality}

LULC change analysis (Fig. 2) results are presented in Table 5. The object-based classification results show that the seven LULC categories (water bodies, vegetation, aquatic, barren/waste land, agriculture, fallow land, builtup area) has changed significantly in the study area during the last 20 -year period. Specifically, the built-up

Table 4 WQI values estimated during the three seasons

\begin{tabular}{|c|c|c|c|c|}
\hline $\begin{array}{l}\text { Sr. } \\
\text { no. }\end{array}$ & Site & WQI (Pre-monsoon) & WQI (monsoon) & WQI (post-monsoon) \\
\hline 1 & Kolans (U/1) & 64.26 (Poor) & 55.86 (Poor) & 48.34 (Good) \\
\hline 2 & Bhori (U/2) & 61.36 (Poor) & 52.86 (Poor) & 43.18 (Good) \\
\hline 3 & Betha. (U/3) & 52.46 (Poor) & 28.09 (Good) & 21.83 Excellent \\
\hline 4 & Bairagarh (U/4) & 61.38 (Poor) & 43.81 (Good) & 33.42 (Good) \\
\hline 5 & Bairagarh East (U/5) & 53.74 (Poor) & 39.50 (Good) & 28.81 (Good) \\
\hline 6 & Khanugau (U/6) & 44.98 (Good) & 23.35 (Excellent) & 14.82 (Excellent) \\
\hline 7 & Karbala (U/7) & 57.18 (Poor) & 35.52 (Good) & 27.10 (Good) \\
\hline 8 & $\begin{array}{l}\text { Medical College (U/ } \\
8)\end{array}$ & 74.37 (Poor) & 72.53 (Poor) & 49.53 (Good) \\
\hline 9 & Kamla Park (U/9) & 40.15 (Good) & 24.59 (Excellent) & 15.65 (Excellent) \\
\hline 10 & Yatch Club (U/10) & 58.19 (Poor) & 50.63 (Poor) & 43.48 (Good) \\
\hline 11 & Ban Vihar (U/11) & 62.95 (Poor) & 50.48 (Poor) & 51.34 (Poor) \\
\hline 12 & Spill Chanel (U/12) & 96.47 (Very Poor) & 80.24 (Very Poor) & 58.73 (Poor) \\
\hline 13 & Bhadbhada (U/13) & $\begin{array}{l}150.83 \text { (Unfit for Drinking } \\
\text { Purposes) }\end{array}$ & $\begin{array}{l}176.86 \text { (Unfit for Drinking } \\
\text { Purposes) }\end{array}$ & $\begin{array}{l}160.91 \text { (Unfit for Drinking } \\
\text { Purposes) }\end{array}$ \\
\hline 14 & Stud Farm (U/14) & 47.31 (Good) & 29.09 (Excellent) & 23.96 (Excellent) \\
\hline \multirow[t]{5}{*}{15} & Bisenkhedi (U/15) & 42.23 (Good) & 19.97 (Excellent) & 15.61 (Excellent) \\
\hline & $\operatorname{Max}$ & 150.83 & 176.86 & 160.91 \\
\hline & Min & 40.15 & 19.97 & 14.82 \\
\hline & Avg & 64.52 & 52.23 & 42.45 \\
\hline & Std & 27.66 & 38.75 & 35.79 \\
\hline
\end{tabular}


area increases from $40 \mathrm{~km}^{2}$ in 2000 to $45 \mathrm{~km}^{2}$ in 2010 with a percentage increase of $1.38 \%$. This increase has probably taken place due to migration of population from rural or non developed areas toward city due to better educational activities, business opportunity and availability of better urban infrastructure facility. The total area of cultivable land decreases from $130 \mathrm{~km}^{2}$ in 2000 to $120 \mathrm{~km}^{2}$ in 2010 with a percentage decrease in $2.77 \%$. The decrease may be mainly due to expansion in urban area. The area of fallow land increased from $90 \mathrm{~km}^{2}$ in 1990 to $95 \mathrm{~km}^{2}$ in 2010 with a percentage increase of $1.38 \%$. Some changes in the quantity of water bodies are also observed, and it decreases around $3 \mathrm{~km}^{2}$ from year 2010 classified satellite image of the study area. This change in the water bodies in the area because of population pressure, changes in rain intensity and deteriorating of water-holding capacity of natural lakes and ponds within the area (Fig. 3).
The vegetation area is $44 \mathrm{~km}^{2}$ in 2000 which increased to $50 \mathrm{~km}^{2}$ in 2010 , indicating a percentage increase of $1.66 \%$. This increase can be attributed to some afforestation activities. The area of waste land has shown a declining trend from 2000 to 2010 , and in year 2000, it is $25 \mathrm{~km}^{2}$ which decreases to $24 \mathrm{~km}^{2}$ in a decade with percentage change of $1 \%$.

The Bhopal, a small town of 1901, started growing rapidly after the becoming a state capital in 1956 and becomes Bhopal Municipal Corporation. The people started migration toward the district for good job opportunities, better infrastructural facilities and education. The district shows tremendous growth after 1971. The population in year 2011 was 23, 68,145 million with growth rate $28.46 \%$. In 2001 census, Bhopal had a population of $1,843,510$ with growth rate 28.62. Bhopal District recorded increase of $36.40 \%$ to its population compared to 1991 . The population density of Bhopal district for 2011 is 855
Fig. 2 Land use/land cover map of Bhopal Lake, 2000

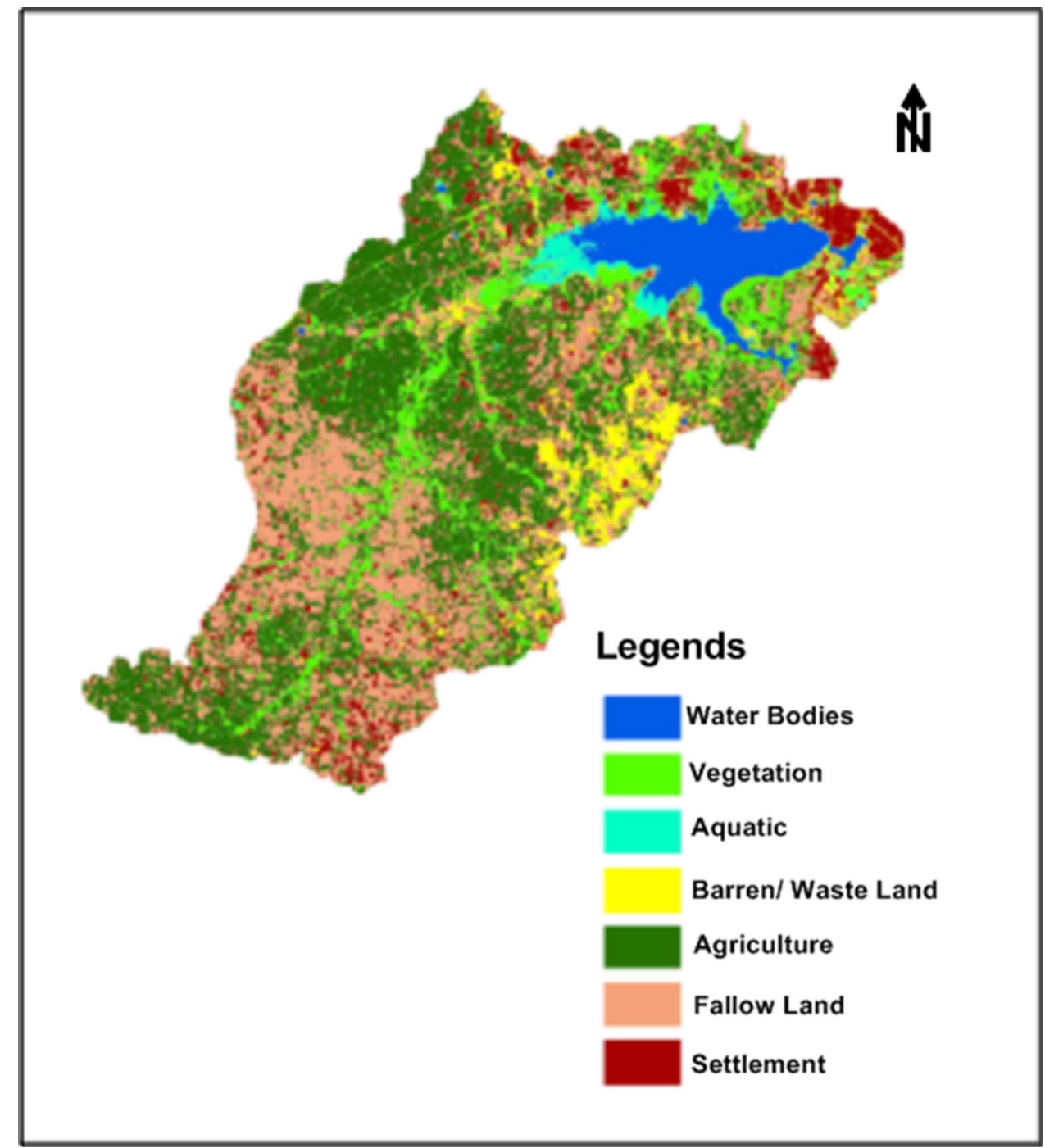


Table 5 Land use/land cover statistics of Bhopal Lake, MP, India

Fig. 3 Land use/land cover map of Bhopal Lake, 2010

\begin{tabular}{|c|c|c|c|c|c|c|c|}
\hline \multirow[t]{2}{*}{ S.No. } & \multirow[t]{2}{*}{ LU/LC } & \multicolumn{2}{|c|}{2000} & \multicolumn{2}{|c|}{2010} & \multicolumn{2}{|l|}{ Change } \\
\hline & & $\mathrm{km}^{2}$ & $\%$ & $\mathrm{~km}^{2}$ & $\%$ & $\mathrm{~km}^{2}(2000-2010)$ & $\%(2000-2010)$ \\
\hline 1 & Water bodies & 23 & 6.37 & 20 & 5.54 & 3 & 0.83 \\
\hline 2 & Vegetation & 44 & 12.18 & 50 & 13.85 & -6 & -1.66 \\
\hline 3 & Aquatic & 9 & 2.49 & 7 & 1.93 & 2 & 0.55 \\
\hline 4 & Barren/waste land & 25 & 6.92 & 24 & 6.64 & 1 & 0.27 \\
\hline 5 & Agriculture & 130 & 36.01 & 120 & 33.24 & 10 & 2.77 \\
\hline 6 & Fallow land & 90 & 24.93 & 95 & 26.31 & -5 & -1.38 \\
\hline \multirow[t]{2}{*}{7} & Settlement & 40 & 11.08 & 45 & 12.46 & -5 & -1.38 \\
\hline & Total & 361 & 100 & 361 & 100 & & \\
\hline
\end{tabular}

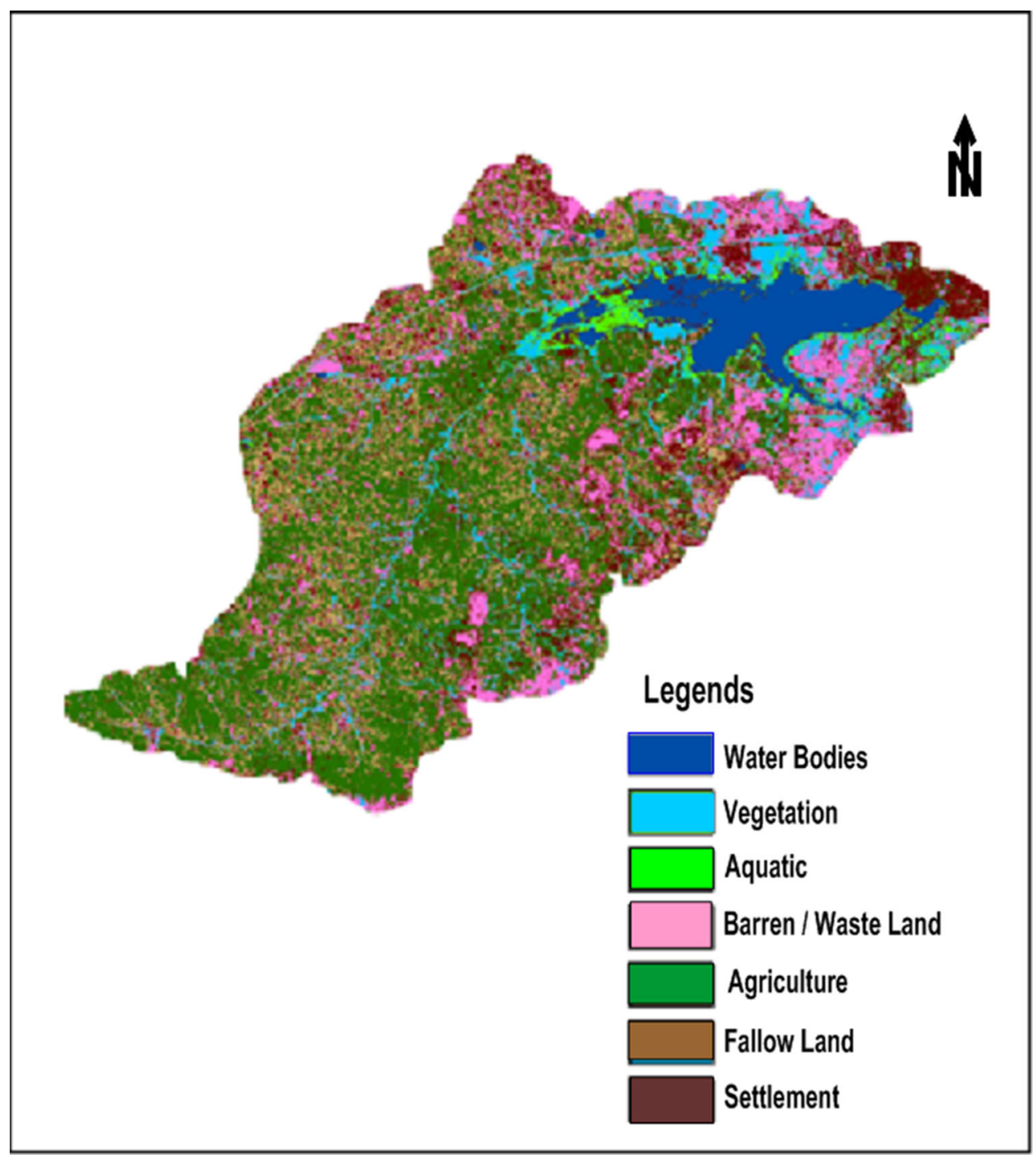

persons $/ \mathrm{km}^{2}$. In 2001, Bhopal district density was at 665 persons $/ \mathrm{km}^{2}$. The continuous increase in population and population density shows that there is continuous and identifiable human pressure on land and water resources of the area.
The urban lake pollution is a very common issue around the world. The urban lakes are getting non treated water as from domestic sewage, industrial effluents, agricultural runoff and siltation due to increased erosion resulting from expansion of urban and agricultural areas, deforestation, 
road construction, and such other land disturbances in the lake catchment area, which deteriorates the quality of lake water. Therefore, the regular monitoring and assessment are a prerequisite to understand the change in water quality.

\section{Multivariate statistical techniques}

The results of PCA analysis are indicated in (Table 6a-c). In the pre-monsoon season, four PCs are extracted. The first PC, accounting for $\sim 48.833 \%$ of total variance, is correlated with representing influences from point sources such as municipal and industrial effluents and soil leaching. This factor is characterized by very high loadings of total alkalinity, calcium, calcium hardness, bicarbonate alkalinity, total phosphorus, phosphate, total hardness, chloride and COD, thus accounting for the temporary hardness of the water. The second factor (which accounts for $23.935 \%$ of the total variance) is mainly associated with very high loading of BOD, magnesium and magnesium hardness. The analysis of second component represents influences from point sources such as from industries. The third PC shows high loading of nitrate and organic phosphorus. This factor ( $\sim 12.688 \%$ variance) probably represents geogenic contribution (Table $6 \mathrm{a}-\mathrm{c})$. The fourth PC $(\sim 5.453 \%)$ has high loading of carbonate alkalinity. In the monsoon season, three components are extracted in which the first PC, accounting for $\sim 60.091 \%$ of the total variance, is correlated with representing influences from point sources such as municipal (possibly laundry industries) and industrial effluents. This factor is characterized by very high loadings of calcium, calcium hardness, phosphate, bicarbonate alkalinity, total hardness, BOD, total alkalinity, total phosphorus, COD and chloride and accounts for the salinity of the water. The second factor (which accounts for $18.230 \%$ of the total variance) is mainly associated with the very high loading of carbonate alkalinity, magnesium and magnesium hardness. The analysis of the second component represents influences from non point sources such as agriculture runoff. The third PC $(\sim 10.756 \%$ variance) is influenced by nitrate, and organic phosphorus represents the laundry influence on lake water. In the postmonsoon, three PCs are extracted, the first PC (48.833\%) is mainly associated with the very high loading of phosphate, calcium, calcium hardness, total phosphorus, chloride, bicarbonate alkalinity, COD, total hardness, BOD and total alkalinity mainly comes from agricultural and domestic sources. The second PC $(23.935 \%)$ is mainly associated with the very high loading of magnesium hardness, magnesium and total hardness. The third PC $(12.688 \%)$ is mainly associated with very high loading organic phosphorus and nitrate. Over here, the samples suffered from all sort of pollution such as industrial waste,
Table 6 Rotated component matrix of (varimax with Kaiser normalization) (a) pre-monsoon (b) monsoon (c) post-monsoon

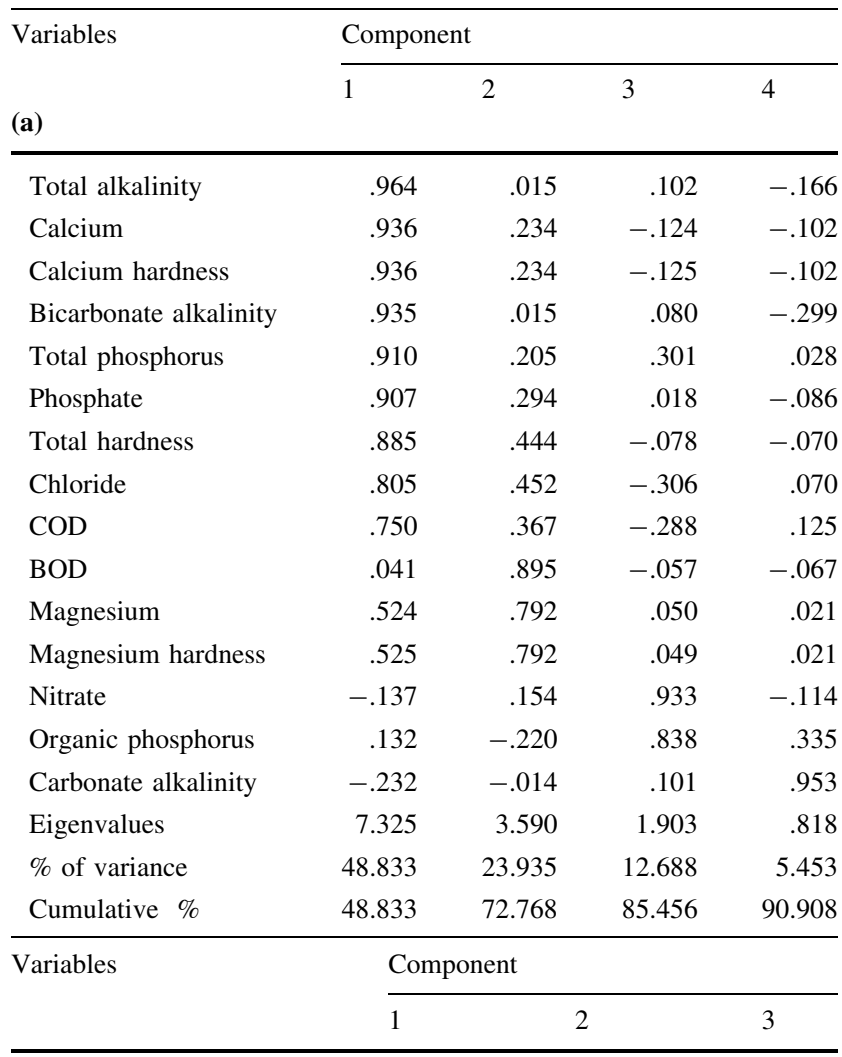

(b)

$\begin{array}{lrrr}\text { Calcium } & .985 & .013 & .034 \\ \text { Calcium hardness } & .985 & .013 & .034 \\ \text { Phosphate } & .964 & .034 & -.102 \\ \text { Bicarbonate alkalinity } & .957 & -.081 & -.091 \\ \text { Total hardness } & .946 & .289 & -.013 \\ \text { BOD } & .938 & .051 & .020 \\ \text { Total alkalinity } & .924 & -.013 & -.112 \\ \text { Total phosphorus } & .877 & -.074 & .414 \\ \text { COD } & .852 & .103 & .053 \\ \text { Chloride } & .783 & .419 & .039 \\ \text { Carbonate alkalinity } & -.641 & .626 & .071 \\ \text { Magnesium } & .140 & .951 & -.154 \\ \text { Magnesium hardness } & .141 & .951 & -.155 \\ \text { Nitrate } & .017 & -.045 & .912 \\ \text { Organic phosphorus } & -.018 & -.185 & .879 \\ \text { Eigenvalues } & 9.014 & 2.735 & 1.613 \\ \text { \% of variance } & 60.091 & 18.230 & 10.756 \\ \text { Cumulative \% } & 60.091 & 78.322 & 89.078 \\ \text { (c) } & & & \\ \text { Phosphate } & .934 & -.127 & -.234 \\ \text { Calcium } & .933 & .259 & .123 \\ \text { Calcium hardness } & .933 & .259 & .123 \\ \text { Total phosphorus } & .873 & -.197 & .395 \\ \text { Chloride } & .866 & .080 & .047 \\ \end{array}$


Table 6 continued

\begin{tabular}{lrrr}
\hline Variables & \multicolumn{2}{l}{ Component } & \\
\cline { 2 - 4 } & \multicolumn{1}{c}{1} & \multicolumn{1}{c}{3} \\
\hline Bicarbonate alkalinity & .859 & -.336 & -.025 \\
COD & .850 & -.095 & -.388 \\
BOD & .745 & .058 & .096 \\
Total alkalinity & .732 & -.512 & -.005 \\
Magnesium hardness & -.166 & .948 & .080 \\
Magnesium & -.165 & .948 & .080 \\
Total hardness & .604 & .767 & .141 \\
Carbonate alkalinity & -.465 & -.501 & .136 \\
Organic phosphorus & .060 & -.132 & .960 \\
Nitrate & .009 & .434 & .835 \\
Eigenvalues & 7.325 & 3.590 & 1.903 \\
\% of variance & 48.833 & 23.935 & 12.688 \\
Cumulative \% & 48.833 & 72.768 & 85.456 \\
\hline
\end{tabular}

agricultural runoff, leaching from waste dumping sites and urban waste.

Table 6 shows statistics derived from the univariate analysis. PCA was actually performed on the correlation matrix between the different parameters followed by Varimax rotation, with the same being used to examine the association between them. This analysis led to the explanation of $85.5 \%$ of the variances in the data. There are 3 dominant factors explaining the geochemistry of the lake water. Factor 1 explains $48.8 \%$ of the total variance and is related to the variables total alkalinity, calcium hardness, bicarbonate alkalinity, total phosphorus, phosphate, total hardness, chloride and COD. Factor 2 accounts for $23.9 \%$ of the total variance and accounts for the organic nutrient factor and has strong loadings for BOD. Factor 3 accounts for $12.6 \%$ of the total variance in pre-monsoon and indicates agricultural sources to the lake water (strong positive loadings for nitrate and phosphorus) in both pre-monsoon and post-monsoon seasons. But in monsoon organic nutrient seems to be controlling $60 \%$ of the total variance (strong loadings in BOD and COD), while factor 2 accounts for $18.2 \%$ of the total variance and factor 3 accounts for $0.7 \%$ of the total variance.

\section{Conclusion}

Curiously, the unique problems and conditions of urban lakes have received little attention in the limnological and watershed management literature. Based on the analytical results obtained from the laboratory, water quality indices are applied to assess the water quality of the area, and the case study proved that the proposed WQI is very informative for long-term monitoring of lake water. The proposed WQI is clearly identifying the type of water quality impairment through the group quality system which helps in initiating the immediate water pollution control actions. The satellite imagery can be used to estimate the LULC and their change over a period of time for area, and these changes can be linked with the lake water quality. From the results of the interpretation of Landsat TM images, the built-up area increased drastically from 2000 to 2010. Further, the LULC analysis and field survey in the study area illustrate a high influence of domestic and agricultural waste during post-monsoon condition. The study reveals that the leaching and runoff, municipal and industrial waste water, and waste disposal sites are the main factors responsible for water quality deterioration with some geogenic contribution from soil and rock weathering.

Acknowledgments The corresponding author expresses his gratefulness to the Founder President Dr. Ashok K. Chauhan and Vice Chancellor Amity University, Noida, for providing facility and constant encouragement for carried out this research work.

\section{References}

Akoto O, Adiyiah J (2007) Chemical analysis of drinking water from some communities in the Brong Ahafo region. Int J Environ Sci Technol 4(2):211-214

American Public Health Association (APHA) (1999) standard methods for the examination of waters and wastewaters, 20th edn. APHA, Washington

Amin A, Fazal S, Mujtaba A, Singh SK (2014) Effects of land transformation on water quality of Dal Lake, Srinagar, India. J Indian Soc Remote Sens 42(1):119-128. doi:10.1007/s12524013-0297-9

Avvannavar SM, Shrihari S (2008) Evaluation of water quality index for drinking purposes for river Netravathi, Mangalore, South India. Environ monit Assess 143(1-3):279-290

Bhopal City Development Plan (2006) Jawaharlal Nehru National Urban Renewal Mission. www.mpurban.gov.in/Pdf/CDP/ Bhopal\%20CDP_Final\%20.pdf

Bordalo AA, Nilsumranchi W, Chalermwat K (2001) Water quality and uses of the Bangpakong River (Eastern Thailand). Water Res 35:3535-3642

Couillard D, Lefebvre Y (1985) Analysis of water quality indexes. J Environ Manage 21:161-179

Gautam SK, Sharma D, Tripathi JK, Ahirwar S, Singh SK (2013) A study of the effectiveness of sewage treatment plants in Delhi region. Appl Water Sci 3(1):57-65. doi:10.1007/s13201-0120059-9

Gautam SK, Maharana C, Sharma D, Singh AK, Tripathi JK, Singh SK (2015) Evaluation of groundwater quality in the Chotanagpur plateau region of the Subarnarekha river basin, Jharkhand State, India. Sustain Water Qual Ecol. doi:10.1016/j.swaqe.2015.06. 001

House MA, Newsome DH (1989) Water quality indices for the management of surface water quality. Water Sci Technol 21:1137-1148

Mishra AK, Garg N (2011) Analysis of trophic state index of Nainital lake from Landsat-7 ETM data. J Indian Soc Remote Sens 39(4):463-471 
Oişte AM (2014) Groundwater quality assessment in urban environment. Int J Environ Sci Technol 11(7):2095-2102

Parmar KS, Bhardwaj R (2013) Water quality index and fractal dimension analysis of water parameters. Int $\mathrm{J}$ Environ Sci Technol 10(1):151-164

Sanchez E, Colmenarejo MF, Vicente J, Rubio A, Garcia MG, Travieso L, Borja R (2007) Use of the water quality index and dissolved oxygen deficit as simple indicators of watersheds pollution. Ecol Indic 7:315-328. doi:10.1016/j.ecolind.2006.02. 005

Shrestha S, Kazama F (2007) Assessment of surface water quality using multivariate statistical techniques: a case study of the Fuji river basin, Japan. Environ Model Softw 22(4):464-475

Singh P, Singh M (2012) A GIS based hydrogeomorphological mapping of basaltic terrain: implications for water resource evaluation and management. In: 13th, ESRI India User Conference, $\mathrm{p} \mathrm{1-8}$

Singh KP, Malik A, Sinha S (2005) Water quality assessment and apportionment of pollution sources of Gomti river (India) using multivariate statistical techniques-a case study. Anal Chim Acta 538(1):355-374

Singh S, Singh C, Kumar K, Gupta R, Mukherjee S (2009) Spatialtemporal monitoring of groundwater using multivariate statistical techniques in Bareilly District of Uttar Pradesh, India. J Hydrol Hydromech 57(1):45-54. doi:10.2478/v10098-0090005-1

Singh SK, Singh CK, Mukherjee S (2010) Impact of land-use and land-cover change on groundwater quality in the Lower Shiwalik hills: a remote sensing and GIS based approach. Cent Eur J Geosci 2(2):124-131. doi:10.2478/v10085-010-0003-x

Singh P, Kumar S, Singh U (2011) Groundwater resource evaluation in the Gwalior area, India, using satellite data: an integrated geomorphological and geophysical approach. Hydrogeol J 19:1421-1429

Singh SK, Srivastava PK, Gupta M, Mukherjee S (2012) Modeling mineral phase change chemistry of groundwater in a rural-urban fringe. Water Sci Technol 66(7):1502-1510

Singh P, Thakur JK, Kumar S (2013a) Delineating groundwater potential zones in a hard-rock terrain using geospatial tool. Hydrol Sci J 58:213-223

Singh P, Thakur JK, Singh UC (2013b) Morphometric analysis of Morar River Basin, Madhya Pradesh, India, using remote sensing and GIS techniques. Environ Earth Sci 68:1967-1977
Singh SK, Srivastava PK, Pandey AC (2013c) Fluoride contamination mapping of groundwater in Northern India integrated with geochemical indicators and GIS. Water Sci Technol Water Supply 13(6):1513-1523

Singh SK, Srivastava PK, Pandey AC, Gautam SK (2013d) Integrated assessment of groundwater influenced by a confluence river system: concurrence with remote sensing and geochemical modelling. Water Resour Mange 24:4291-4313. doi:10.1007/ 511269-013-0408-y

Singh SK, Singh D, Han D, Gautam SK (2015) Modelling groundwater quality over a humid subtropical region using numerical indices, earth observation datasets, and X-ray diffraction technique: a case study of Allahabad district. Environ Geochem Health. doi:10.1007/s10653-014-9638-z

Sinha DK, Saxena R (2006) Statistical assessment of underground drinking water contamination and effects of monsoon at Hasanpur, J.P. Nagar (Uttar Pradesh, India). J Environ Sci Engg 48(3):157-164

Smith DG (1989) A new form of water quality index for rivers and streams. Water Sci Technol 21:123-127

Snow J (1856) Cholera and the water supply in the south districts of London in 1854. T. Richards, London

Srivastava PK, Mukherjee S, Gupta M (2010) Impact of urbanization on land use/land cover change using remote sensing and GIS: a case study. Int J Ecol Econ Stat 18(S10):106-117

Srivastava PK, Gupta M, Mukherjee S (2012) Mapping spatial distribution of pollutants in groundwater of a tropical area of India using remote sensing and GIS. Appl Geomat 4(1):21-32. doi:10.1007/s12518-011-0072-y

Swamee PK, Tyagi A (2000) Describing water quality with aggregate index. J Environ Eng 126:451-455

Thakur JK, Diwakar J, Singh SK (2015) Hydrogeochemical evaluation of groundwater of Bhakatpur Muncipality Nepal. Environ Earth Sci. doi:10.1007/512665-015-4514-4

Tiwari T, Mishra M (1985) A preliminary assignment of water quality index of major Indian rivers. Indian J Environ Prot 5(4):276-279

Vasanthavigar M, Srinivasamoorthy K, Vijayaragavan K, Ganthi RR, Chidambaram S, Anandhan P, Manivannan R, Vasudevan S (2010) Application of water quality index for groundwater quality assessment: thirumanimuttar sub-basin, Tamilnadu, India. Environ Monit Assess 171(1-4):595-609 